\title{
Stimulation of Suicidal Erythrocyte Death by Ipratropium Bromide
}

\author{
Nazneen Shaik ${ }^{a}$ Eyad Alhourania Anastasia Bosc Guilai Liu Syeda Towhid \\ Adrian Lupescu Florian Lang
}

Department of Physiology, University of Tuebingen, Tuebingen; "those authors contributed equally and thus share first authorship

\section{Key Words}

Phosphatidylserine $\cdot$ Ipratropium bromide $\bullet$ Calcium $•$ Cell volume $\bullet$ Eryptosis

\begin{abstract}
Background/Aims: Ipratropium bromide, an anticholinergic agent widely used in obstructive lung disease, has previously been shown to trigger suicidal death of nucleated cells or apoptosis. Despite their lack of mitochondria and nuclei, key organelles in the execution of apoptosis, erythrocytes may similarly undergo suicidal cell death, which is characterized by cell shrinkage and by cell membrane scrambling with phosphatidylserine-exposure at the cell surface. Triggers of eryptosis include increase of cytosolic $\mathrm{Ca}^{2+}$-activity $\left(\left[\mathrm{Ca}^{2+}\right]_{\mathrm{i}}\right)$. The present study explored whether ipratropium bromide triggers eryptosis. Methods: $\left[\mathrm{Ca}^{2+}\right]_{i}$ was estimated utilizing Fluo3 fluorescence, cell volume from forward scatter, phosphatidylserine-exposure from annexin-V-binding, and hemolysis from hemoglobin release. Results: A $48 \mathrm{~h}$ exposure to ipratropium bromide $(1 \mathrm{nM})$ significantly increased $\left[\mathrm{Ca}^{2+}\right]_{\mathrm{i}^{\prime}}$ decreased forward scatter and increased annexin-V-binding. Ipratropium bromide treatment was followed by slight but significant increase of hemolysis. Removal of extracellular $\mathrm{Ca}^{2+}$ or inhibition of $\mathrm{Ca}^{2+}$ permeable cation channels with amiloride $(1 \mathrm{mM})$ virtually abolished cell membrane scrambling. $\mathrm{Ca}^{2+}$ ionophore ionomycin ( $1 \mu \mathrm{M}, 30 \mathrm{~min})$ increased the percentage of phosphatidylserine exposing erythrocytes to similarly high levels in the absence and presence of ipratropium bromide (1 nM). Conclusions: Ipratropium bromide triggers suicidal erythrocyte death or eryptosis, an effect mainly due to stimulation of $\mathrm{Ca}^{2+}$-entry.
\end{abstract}

\section{Introduction}

Copyright $(2012$ S. Karger AG, Basel

Ipratropium bromide, a nonselective antagonist of the muscarinic receptors located on airway smooth muscle [1], is widely used to counteract rhinorrhea of common cold [2], asthma and chronic obstructive pulmonary disease (COPD) [3-7] as well as prevention of 
the Arthus reaction [8]. When applied locally, the drug is well tolerated [2]. Advantages of the drug include its limited systemic absorption from the lungs when given as an inhaled preparation [4].

In order to gain some insight into cellular toxicity of ipratropium bromide, the present study explored, whether the drug triggers suicidal erythrocyte death or eryptosis. Similar to apoptosis of nucleated cells, suicidal erythrocyte death or eryptosis is charactrerized by cell membrane scrambling and cell shrinkage [9]. Eryptosis is triggered by a wide variety of xenobiotics [10-21]. They are in part effective by stimulating $\mathrm{Ca}^{2+}$ entry through $\mathrm{Ca}^{2+}$-permeable cation channels $[22,23]$ thus increasing cytosolic $\mathrm{Ca}^{2+}$ concentration. $\mathrm{Ca}^{2+}$ activates $\mathrm{Ca}^{2+}$-sensitive $\mathrm{K}^{+}$channels [24] resulting in $\mathrm{K}^{+}$exit, hyperpolarization, $\mathrm{Cl}^{-}$exit, cellular loss of $\mathrm{KCl}$ together with osmotically obliged water and thus cell shrinkage [25]. $\mathrm{Ca}^{2+}$ further triggers cell membrane scrambling with phosphatidylserine exposure at the cell surface [26]. Erythrocytes are sensitized to the cell membrane scrambling effect of $\mathrm{Ca}^{2+}$ by ceramide, which thus similarly stimulates eryptosis [27]. Eryptosis is further stimulated by energy depletion [28] and activation of caspases [18, 29-32]. Cell membrane scrambling is further influenced by AMP activated kinase AMPK [23], cGMP-dependent protein kinase [33] and Janus-activated kinase JAK3 [10].

\section{Materials and Methods}

\section{Erythrocytes, solutions and chemicals}

Leukocyte-depleted erythrocytes were kindly provided by the blood bank of the University of Tübingen. The study is approved by the ethics committee of the University of Tübingen (184/2003V). Erythrocytes were incubated in vitro at a hematocrit of $0.4 \%$ in Ringer solution containing (in mM) $125 \mathrm{NaCl}, 5 \mathrm{KCl}, 1 \mathrm{MgSO}_{4}$, $32 \mathrm{~N}$-2-hydroxyethylpiperazine- $\mathrm{N}$-2-ethanesulfonic acid (HEPES), 5 glucose, $1 \mathrm{CaCl}_{2} ; \mathrm{pH} 7.4$ at $37^{\circ} \mathrm{C}$ for $48 \mathrm{~h}$. Where indicated, erythrocytes were exposed to ipratropium bromide (Tocris, Bristol, U.K.) at the indicated concentrations. In $\mathrm{Ca}^{2+}$-free Ringer solution, $1 \mathrm{mM} \mathrm{CaCl}_{2}$ was substituted by $1 \mathrm{mM}$ glycol-bis(2-aminoethylether)$\mathrm{N}, \mathrm{N}, \mathrm{N}, \mathrm{N}^{\prime}$-tetraacetic acid (EGTA).

\section{FACS analysis of annexin-V-binding and forward scatter}

After incubation under the respective experimental condition, $50 \mu \mathrm{l}$ cell suspension was washed in Ringer solution containing $5 \mathrm{mM} \mathrm{CaCl}_{2}$ and then stained with Annexin-V-FITC (1:200 dilution; ImmunoTools, Friesoythe, Germany) in this solution at $37^{\circ} \mathrm{C}$ for $20 \mathrm{~min}$ under protection from light. In the following, the forward scatter (FSC) of the cells was determined, and annexin- $V$ fluorescence intensity was measured in FL-1 with an excitation wavelength of $488 \mathrm{~nm}$ and an emission wavelength of $530 \mathrm{~nm}$ on a FACS Calibur (BD, Heidelberg, Germany).

\section{Measurement of intracellular $\mathrm{Ca}^{2+}$}

After incubation erythrocytes were washed in Ringer solution and then loaded with Fluo-3/AM (Biotium, Hayward, USA) in Ringer solution containing $5 \mathrm{mM} \mathrm{CaCl}_{2}$ and $2 \mu \mathrm{M}$ Fluo-3/AM. The cells were incubated at $37^{\circ} \mathrm{C}$ for $30 \mathrm{~min}$ and washed twice in Ringer solution containing $5 \mathrm{mM} \mathrm{CaCl}$. The Fluo-3/AMloaded erythrocytes were resuspended in $200 \mu \mathrm{l}$ Ringer. Then, $\mathrm{Ca}^{2+}$-dependent fluorescence intensity was measured in fluorescence channel FL-1 in FACS analysis.

\section{Measurement of hemolysis}

For the determination of hemolysis the samples were centrifuged ( $3 \mathrm{~min}$ at $400 \mathrm{~g}$, room temperature) after incubation, and the supernatants were harvested. As a measure of hemolysis, the hemoglobin $(\mathrm{Hb})$ concentration of the supernatant was determined photometrically at $405 \mathrm{~nm}$. The absorption of the supernatant of erythrocytes lysed in distilled water was defined as $100 \%$ hemolysis.

CaCo cells were grown in DMEM medium containing 10\% fetal calf serum under standard culture conditions $\left(37^{\circ} \mathrm{C}, 5 \% \mathrm{CO}_{2}\right) \cdot 10^{5}$ cells were seeded in 6 well plates and cultivated with fresh culture medium 
Fig. 1. Effect of ipratropium bromide on erythrocyte forward scatter. A. Original histogram of forward scatter of erythrocytes following exposure for $48 \mathrm{~h}$ to Ringer solution without (-, black line) and with $(+$, red line) presence of $1 \mathrm{nM}$ ipratropium bromide. B. Arithmetic means \pm SEM $(n=8)$ of the normalized erythrocyte forward scatter (FSC) following incubation for 48

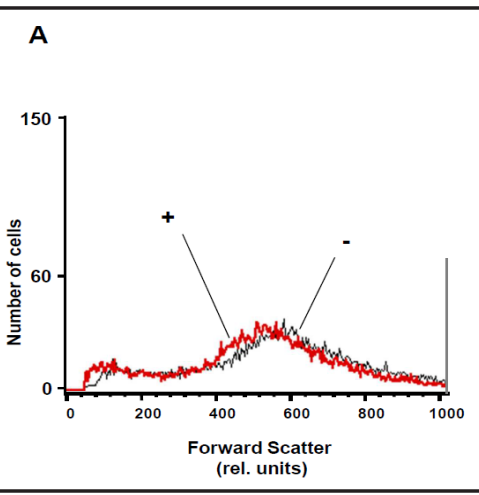

B

$\mathrm{h}$ to Ringer solution without (white bar) or with (black bars) ipratropium bromide $(0.1-1 \mathrm{nM}) .^{*}(\mathrm{p}<0.05)$ indicates significant difference from the absence of ipratropium bromide (ANOVA).

for $24 \mathrm{~h}$. The cells were incubated in the absence or presence of $1 \mathrm{nM}$ ipratropium for 24 hours. Then, apoptosis was determined by fixing the cells for 30 minutes in $70 \%$ ice-cold ethanol followed by staining the fixed cells with a combination of 1:200 Annexin V-FITC 1:200 dilution (ImmunoTools, Friesoythe, Germany) and $50 \mu \mathrm{g} / \mathrm{ml}$ propidium iodide (PI) (Mabtag, Friesoythe, Germany) in the dark on ice for 60 minutes. The cells were washed once in PBS and analyzed immediately in FL-1/FL-2 in BD FACS Calibur. Annexin-V FITC and PI double positive cells were considered to be apoptotic.

\section{Statistics}

For FACS analysis each single value represents the average of $10^{4}$ cells. Arithmetic means \pm standard error of the mean (SEM) were calculated from the average values of different erythrocyte batches. SEM was taken to provide an estimate of the statistical certainty of the arithmetic means. As indicated in the figure legends, statistical analysis was made using ANOVA with Tukey's test as post-test and $t$ test as appropriate. $n$ denotes the number of different erythrocyte specimens studied. Since different erythrocyte specimens used in distinct experiments are differently susceptible to triggers of eryptosis, the same erythrocyte specimens have been used for control and experimental conditions.

\section{Results}

The present study explored, whether ipratropium bromide triggers suicidal erythrocyte death. A hallmark of eryptosis is cell shrinkage. Thus, forward scatter has been determined in FACS analysis to estimate cell volume. As shown in Fig. 1, ipratropium bromide treatment decreased forward scatter, an effect statistically significant at $0.4 \mathrm{nM}$ ipratropium bromide.

Another hallmark of eryptosis is cell membrane scrambling with phosphatidylserine exposure at the cell surface. In order to test whether ipratropium bromide treatment results in cell membrane scrambling, phosphatidylserine exposing erythrocytes were identified utilizing annexin-V-binding, as determined by FACS analysis. As shown in Fig. 2, a $48 \mathrm{~h}$ exposure to ipratropium bromide increased the percentage of annexin-V-binding erythrocytes, an effect reaching statistical significance at $0.4 \mathrm{nM}$ ipratropium bromide.

Additional experiments were performed to explore whether ipratropium bromide triggered hemolysis. To this end, hemolysis was estimated from hemoglobin release into the supernatant. As shown in Fig. 2, exposure of erythrocytes for $48 \mathrm{~h}$ to ipratropium bromide was followed by an increase of hemoglobin concentration in the supernatant, an effect reaching statistical significance at $0.8 \mathrm{nM}$ ipratropium bromide concentration (Fig. 2B). The percentage of hemolysed erythrocytes was, however, almost one order of magnitude smaller than the percentage of phosphatidylserine exposing cells. 


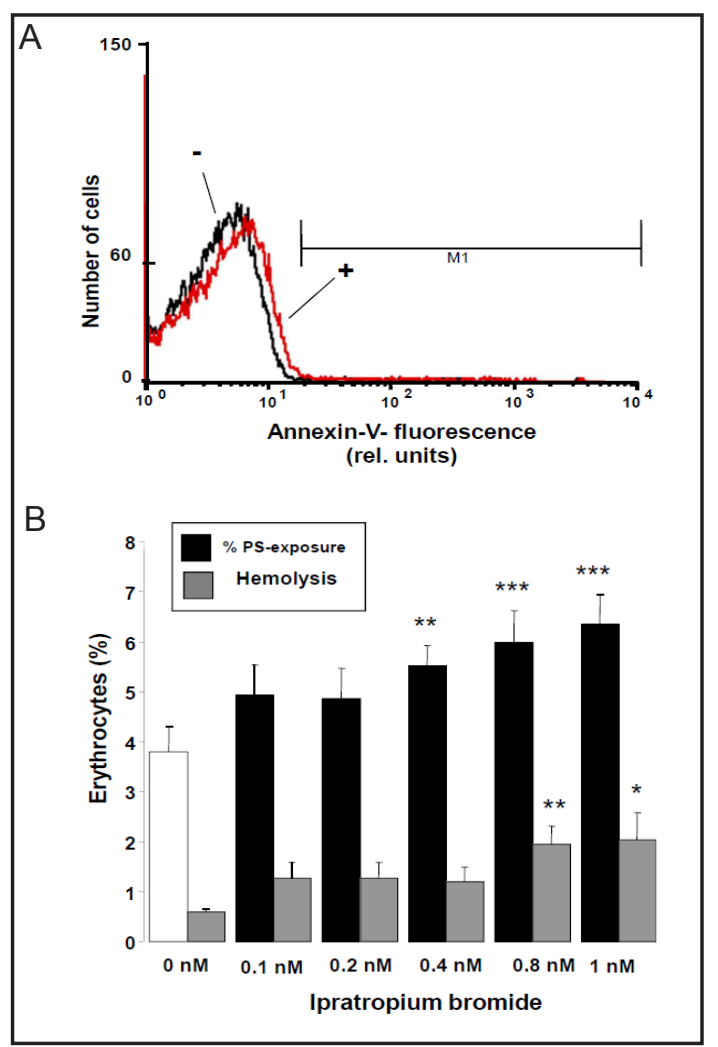

Fig. 2. Effect of ipratropium bromide on phosphatidylserine exposure and hemolysis. A. Original histogram of annexin-V-binding of erythrocytes following exposure for $48 \mathrm{~h}$ to Ringer solution without (-, black line) and with $(+$, red line) presence of $1 \mathrm{nM}$ ipatropium bromide. B. Arithmetic means \pm SEM of erythrocyte annexin-V-binding $(n=8)$ following incubation for $48 \mathrm{~h}$ to Ringer solution without (white bar) or with (black bars) presence of ipratropium bromide (0.1 -1 $\mathrm{nM})$. For comparison, arithmetic means \pm SEM $(n=4)$ of the percentage of hemolysis is shown as grey bars. ${ }^{*}(\mathrm{p}<0.05),{ }^{* *}(\mathrm{p}<0.001),{ }^{* *}(\mathrm{p}<0.001)$ indicates significant difference from the absence of ipratropium bromide (ANOVA).

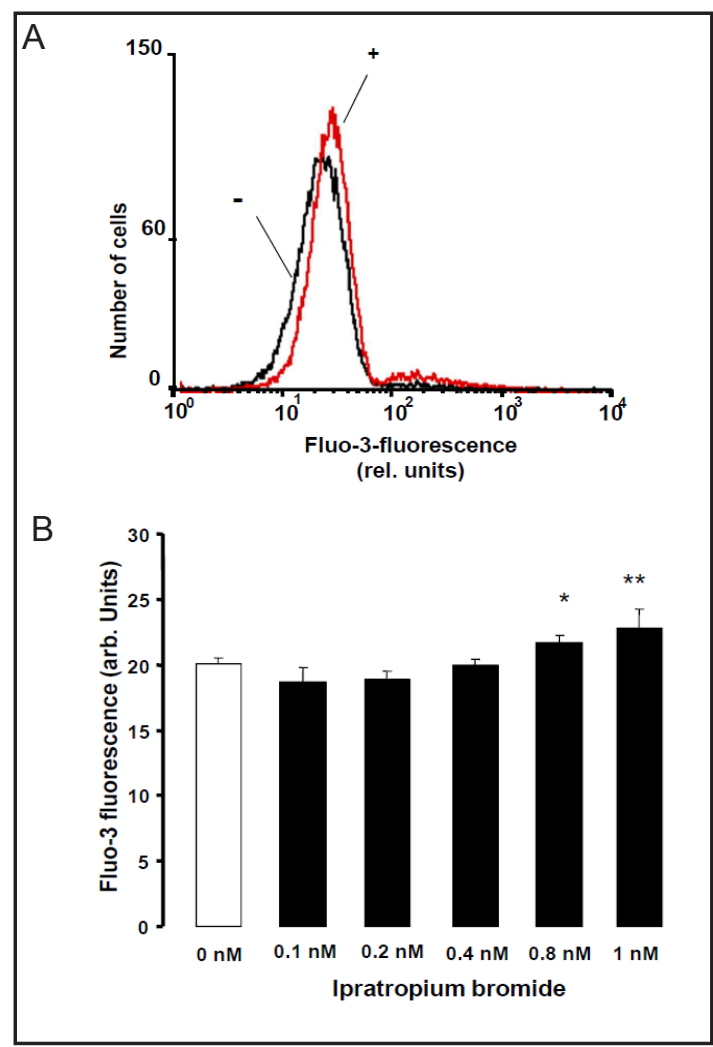

Fig. 3. Effect of ipratropium bromide on erythrocyte cytosolic $\mathrm{Ca}^{2+}$ concentration. A. Original histogram of Fluo3 fluorescence in erythrocytes following exposure for $48 \mathrm{~h}$ to Ringer solution without (-, black line) and with $(+$, red line) presence of 1 $n M$ ipatropium bromide. B. Arithmetic means \pm SEM $(n=8)$ of the normalized histogram in arbitrary units of Fluo3 fluorescence in erythrocytes exposed for $48 \mathrm{~h}$ to Ringer solution without (white bar) or with (black bars) ipratropium bromide $(0.1-1$ $\mathrm{nM}){ }^{*}(\mathrm{p}<0.05),{ }^{* *}(\mathrm{p}<0.001)$, indicates significant difference from the absence of ipratropium bromide (ANOVA).

As both, cell shrinkage and cell membrane scrambling could result from increase of cytosolic $\mathrm{Ca}^{2+}$ activity, additional experiments explored the effect of ipratropium bromide on cytosolic $\mathrm{Ca}^{2+}$ activity. To this end, cytosolic $\mathrm{Ca}^{2+}$ was estimated by Fluo3 fluorescence. As illustrated in Fig. 3, treatment with ipratropium bromide was followed by a slight increase of Fluo3 fluorescence, an effect reaching statistical significance at $0.8 \mathrm{nM}$.

A further series of experiments explored whether the observed ipratropium bromide induced cell membrane scrambling required $\mathrm{Ca}^{2+}$ entry. To this end, erythrocytes were exposed to $1 \mathrm{nM}$ ipratropium bromide in the presence or in the nominal absence of extracellular $\mathrm{Ca}^{2+}$. As illustrated in Fig. 4, the effect of ipratropium bromide on annexin-V-binding was virtually abolished in the nominal absence of $\mathrm{Ca}^{2+}$.

$\mathrm{Ca}^{2+}$ entry into erythrocytes could be accomplished by opening of amiloride sensitive cation channels. In order to test whether those channels were involved in the effect of 


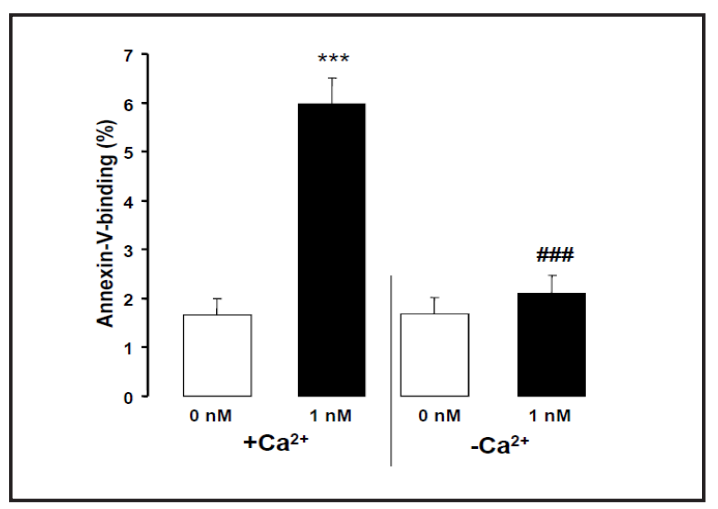

Fig. 4. Effect of $\mathrm{Ca}^{2+}$ withdrawal on ipratropium bromide-induced annexin-V-binding. Arithmetic means \pm SEM $(n=4)$ of the percentage of annexinV-binding erythrocytes after a $48 \mathrm{~h}$ treatment with Ringer solution without (white bar) or with (black bars) $1 \mathrm{nM}$ ipratropium bromide in the presence (left bars, $+\mathrm{Ca}^{2+}$ ) and absence (right bars, $-\mathrm{Ca}^{2+}$ ) of calcium. $* * *(\mathrm{p}<0.001)$ indicates significant difference from the absence of ipratropium bromide (ANOVA). \#\#\# $(p<0.001)$ indicates significant difference from the respective values in the presence of $\mathrm{Ca}^{2+}$.

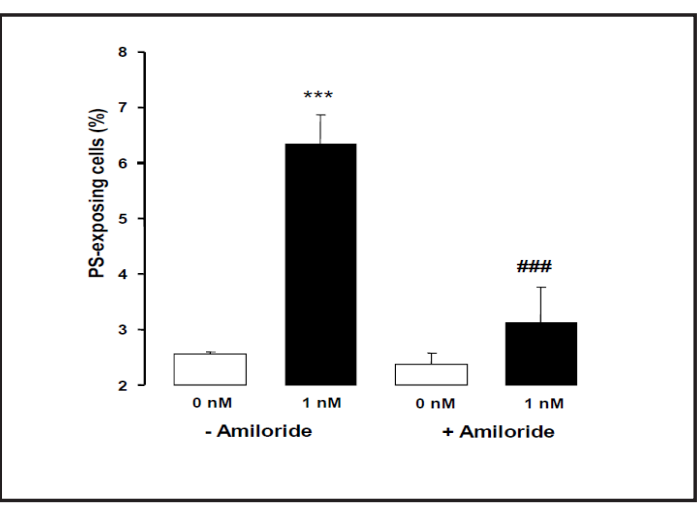

Fig. 5. Effect of cation channel blocker amiloride on ipratropium bromide- induced annexin-V-binding. Arithmetic means \pm SEM $(n=4)$ of the percentage of annexin-V-binding erythrocytes after a $48 \mathrm{~h}$ treatment with Ringer solution without (white bar) or with (black bars) $1 \mathrm{nM}$ ipratropium bromide in the absence (left bars, - amiloride) and presence (right bars, + amiloride) of amiloride $(1 \mathrm{mM})$. ${ }^{* * *}$ $(p<0.001)$ indicates significant difference from the absence of ipratropium bromide (ANOVA). \#\#\# $(\mathrm{p}<0.001)$ indicates significant difference from the respective values in the absence of amiloride.

Fig. 6. Effect of ipratropium bromide on ionomycininduced annexin-V-binding. Arithmetic means \pm SEM $(n=4)$ of the percentage of annexin-V-binding erythrocytes after a 30 min treatment with Ringer solution without (white bar) or with (black bars) 1 $\mathrm{nM}$ ipratropium bromide in the absence (left bars, -ionomycin) and presence (right bars, +ionomycin) of $\mathrm{Ca}^{2+}$ ionophore ionomycin $(1 \mu \mathrm{M}) .{ }^{*}(\mathrm{p}<0.05)$ indicates significant difference from the absence of ipratropium bromide (ANOVA). \#\#\# ( $p<0.001)$ indicates significant difference from the respective values in the absence of ionomycin.

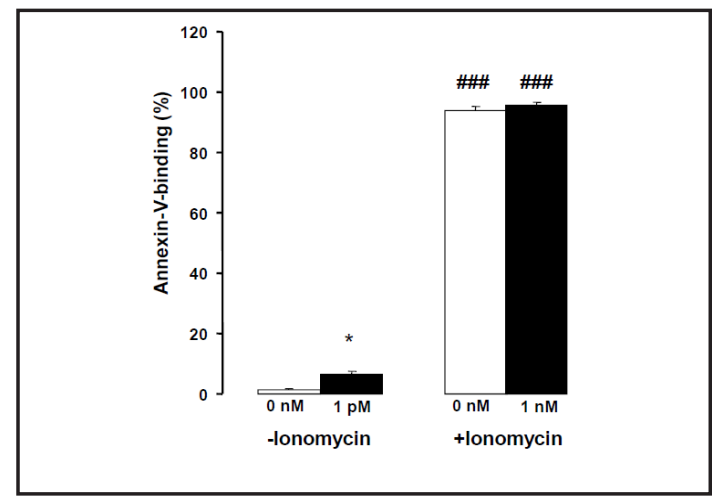

ipratropium bromide on cell membrane scrambling, erythrocytes were treated with $1 \mathrm{nM}$ ipratropium bromide in the absence or presence of amiloride $(1 \mathrm{nM})$. As illustrated in Fig. 5 , the effect of ipratropium bromide on annexin-V-binding was virtually abrogated in the presence of amiloride.

An additional series of experiments explored whether the difference in cell membrane scrambling between presence or absence of ipratropium bromide could be attenuated by treatment of the erythrocytes with the $\mathrm{Ca}^{2+}$ ionophore ionomycin $(1 \mu \mathrm{M})$. As illustrated in Fig. 6, the exposure of erythrocytes to ionomycin was followed by a marked increase of the percentage phosphatidylserine exposing erythrocytes to similarly high levels in the presence or absence of $1 \mathrm{nM}$ ipratropium bromide. This observation suggests that ipratropium bromide is mainly effective through increase of cytosolic $\mathrm{Ca}^{2+}$ activity. 
To elucidate whether $1 \mathrm{nM}$ ipratropium bromide is similarly effective in nucleated cells, additional experiments were performed in CaCo cells. As a result, the exposure to 1 $\mathrm{nM}$ ipratropium bromide for 24 hours was followed by an increase of annexin-V-binding in $3.4 \pm 0.8 \%(\mathrm{n}=11)$ of CaCo cells, a value significantly $(\mathrm{p}<0.05)$ higher as in CaCo cells without ipratropium bromide treatment $(1.4 \pm 0.4 \%, n=11)$. The forward scatter tended to be lower in ipratropium bromide treated CaCo cells $(614 \pm 7 \%, \mathrm{n}=11)$ than in untreated CaCo cells $(633 \pm 7 \%, \mathrm{n}=11)$, an effect, however, not reaching statistical significance $(\mathrm{p}=0.06)$. The percentage of CaCo cells entering late apoptosis approached $0.8 \pm 0.1 \%$ $(\mathrm{n}=4)$ without and $3.5 \pm 0.7 \%(\mathrm{n}=5)$ with prior ipratropium bromide treatment for 24 hours, values significantly $(\mathrm{p}<0.05)$ different.

\section{Discussion}

The present observations show for the first time that ipratropium bromide triggers eryptosis, the suicidal death of erythrocytes. Ipratropium bromide exposure elicits erythrocyte membrane scrambling and leads to erythrocyte shrinkage.

According to the present observations, ipratropium bromide increases cytosolic $\mathrm{Ca}^{2+}$ activity, an effect presumably resulting from activation of non-selective cation channels. It is noteworthy that the erythrocyte cation channels are activated by oxidative stress [34]. The molecular identity of the $\mathrm{Ca}^{2+}$ permeable erythrocyte cation channels remained ill-defined but has been shown to somehow involve the transient receptor potential channel TRPC6 [22].

The increase of cytosolic $\mathrm{Ca}^{2+}$ activity presumeably accounts for the effect of ipratropium bromide on forward scatter. The increase of cytosolic $\mathrm{Ca}^{2+}$ concentration leads to activation of $\mathrm{Ca}^{2+}$ sensitive $\mathrm{K}^{+}$channels $[24,35]$ with subsequent exit of $\mathrm{K}^{+}$following its chemical gradient, hyperpolarization of the cell membrane, electrically driven exit of $\mathrm{Cl}^{-}$and thus cellular loss of KCl followed by osmotically obliged water [25]. The exit of water leads to cell shrinkage, which is apparent from the decrease of forward scatter.

An increase of cytosolic $\mathrm{Ca}^{2+}$ activity further stimulates cell membrane scrambling with phosphatidylserine exposure at the erythrocyte surface [26, 36, 37]. The scrambling effect of ipratropium bromide was virtually abrogated in the nominal absence of extracellular $\mathrm{Ca}^{2+}$, indicating that ipratropium bromide was mainly effective by increasing cytosolic $\mathrm{Ca}^{2+}$ activity. The scrambling effect of ipratropium bromide was further blunted in the presence of the cation channel blocker amiloride, suggesting that ipratropium bromide activated the unspecific, $\mathrm{Ca}^{2+}$ permeable cation channels of erythrocytes.

Apparently, ipratropium bromide did not modify $\mathrm{Ca}^{2+}$ sensitivity of cell membrane scrambling, as the $\mathrm{Ca}^{2+}$ ionophore ionomycin was similarly effective in the presence and absence of ipratropium bromide.

As observed following stimulation with other challenges [27,29], only a small percentage of erythrocytes entered eryptosis following treatment with ipratropium bromide $(\approx 6 \%)$ which was approximately twice the percentage of eryptotic erythrocytes in the absence of ipratropium bromide $(\approx 2.5-3.8 \%)$. Without the respective increase of erythropoiesis this effect would sustantially decrease the number of circulating erythrocytes. The sensitivity of erythrocytes to stimulators of eryptosis may depend on erythrocyte age [38].

The concentration required for the effects of ipratropium bromide on cell membrane scrambling is in the range of the ipratropium bromide concentrations observed in vivo [39]. However, the substance is mainly applied locally by inhalation, which limits its concentrations in circulating blood $[2,4]$. The observed stimulation of eryptosis may thus occur only at inadequate use of the drug. Nevertheless eryptosis may be relevant in individuals with diseases triggering of eryptosis. Enhanced eryptosis has been observed in a variety of clinical disorders [9], including diabetes [32, 40, 41], renal insufficiency [42], hemolytic uremic 
syndrome [43], sepsis [44], sickle cell disease [45]. malaria [46-50], Wilson's disease [50], iron deficiency [51], phosphate depletion [52] and presumably metabolic syndrome [53].

Phosphatidylserine exposing erythrocytes are rapidly cleared from circulating blood and excessive eryptosis may thus lead to anemia [9]. Moreover, phosphatidylserine exposing erythrocytes adhere to endothelial CXCL16/SR-PSO [54] with subsequent impairment of microcirculation [54-59]. Phosphatidylserine exposing erythrocytes further stimulate blood clotting $[55,60,61]$. Thus, excessive eryptosis may lead to thrombosis.

At least in theory, ipratropium bromide could similarly trigger $\mathrm{Ca}^{2+}$ entry and cell membrane scrambling of nucleated cells. Owing to the limited systemic absorption from the lungs when given as an inhaled preparation [4], ipratropium bromide does, presumably, rarely approach cytotoxic concentrations in blood.

\section{Conclusion}

In conclusion, ipratropium bromide stimulates amiloride sensitive $\mathrm{Ca}^{2+}$ entry with subsequent increase of cytosolic $\mathrm{Ca}^{2+}$ activity, stimulation of $\mathrm{Ca}^{2+}$ sensitive $\mathrm{K}^{+}$channels and $\mathrm{Ca}^{2+}$ dependent triggering of cell membrane scrambling. Thus, ipratropium bromide elicits eryptosis, the suicidal death of erythrocytes.

\section{Acknowledgements}

The authors acknowledge the meticulous preparation of the manuscript by Ali Soleimanpour. This study was supported by the Deutsche Forschungsgemeinschaft.

\section{References}

1 Wellington K: Ipratropium bromide HFA. Treat Respir Med 2005;4:215-220.

2 Graf P, Eccles R, Chen S: Efficacy and safety of intranasal xylometazoline and ipratropium in patients with common cold. Expert Opin Pharmacother 2009;10:889-908.

- G Gordon J, Panos RJ: Inhaled albuterol/salbutamol and ipratropium bromide and their combination in the treatment of chronic obstructive pulmonary disease. Expert Opin Drug Metab Toxicol 2010;6:381-392.

-4 Dotson K, Dallman M, Bowman CM, Titus MO: Ipratropium bromide for acute asthma exacerbations in the emergency setting: a literature review of the evidence. Pediatr Emerg Care 2009;25:687-692.

5 Appleton S, Jones T, Poole P, Pilotto L, Adams R, Lasserson TJ, Smith B, Muhammad J: Ipratropium bromide versus long-acting beta-2 agonists for stable chronic obstructive pulmonary disease. Cochrane Database Syst Rev 2006;CD006101.

6 Zhang W, Fievez L, Zhang F, Cheu E, Antoine N, Delguste C, Zhang Y, Rong W, Bureau F, Advenier C, Gustin P: Effects of formoterol and ipratropium bromide on repeated cadmium inhalation-induced pulmonary inflammation and emphysema in rats. Eur J Pharmacol 2010;647:178-187.

7 Jiang JX, Cao R, Deng WD, Jin F, Dong XW, Zhu Y, Chen XP, Xie YC, Bao MJ, Li FF, Xie QM: Characterization of bencycloquidium bromide, a novel muscarinic $\mathrm{M}(3)$ receptor antagonist in guinea pig airways. Eur J Pharmacol 2011;655:74-82.

8 Nezhinskaya GI, Sapronov NS, Vladykin AL, Shepeleva VV: Effects of cholinotropic and cytostatic drugs on the development of Arthus reaction. Bull Exp Biol Med 2008;146:747-749.

-9 Lang F, Gulbins E, Lerche H, Huber SM, Kempe DS, Foller M: Eryptosis, a window to systemic disease. Cell Physiol Biochem 2008;22:373-380.

10 Bhavsar SK, Gu S, Bobbala D, Lang F: Janus kinase 3 is expressed in erythrocytes, phosphorylated upon energy depletion and involved in the regulation of suicidal erythrocyte death. Cell Physiol Biochem 2011;27:547-556.

11 Felder KM, Hoelzle K, Ritzmann M, Kilchling T, Schiele D, Heinritzi K, Groebel K, Hoelzle LE: Hemotrophic mycoplasmas induce programmed cell death in red blood cells. Cell Physiol Biochem 2011;27:557-564.

12 Gatidis S, Zelenak C, Fajol A, Lang E, Jilani K, Michael D, Qadri SM, Lang F: p38 MAPK Activation and Function following Osmotic Shock of Erythrocytes. Cell Physiol Biochem 2011;28:1279-1286. 
13 Ghashghaeinia M, Toulany M, Saki M, Bobbala D, Fehrenbacher B, Rupec R, Rodemann HP, Ghoreschi K, Rocken M, Schaller M, Lang F, Wieder T: The NFкB Pathway Inhibitors Bay 11-7082 and Parthenolide Induce Programmed Cell Death in Anucleated Erythrocytes. Cell Physiol Biochem 2011;27:45-54.

14 Lang E, Jilani K, Zelenak C, Pasham V, Bobbala D, Qadri SM, Lang F: Stimulation of suicidal erythrocyte death by benzethonium. Cell Physiol Biochem 2011;28:347-354.

15 Nguyen DB, Wagner-Britz L, Maia S, Steffen P, Wagner C, Kaestner L, Bernhardt I: Regulation of phosphatidylserine exposure in red blood cells. Cell Physiol Biochem 2011;28:847-856.

-16 Qadri SM, Kucherenko Y, Zelenak C, Jilani K, Lang E, Lang F: Dicoumarol Activates Ca-permeable Cation Channels Triggering Erythrocyte Cell Membrane Scrambling. Cell Physiol Biochem 2011;28:857-864.

17 Qadri SM, Bauer J, Zelenak C, Mahmud H, Kucherenko Y, Lee SH, Ferlinz K, Lang F: Sphingosine but not sphingosine-1-phosphate stimulates suicidal erythrocyte death. Cell Physiol Biochem 2011;28:339-346.

18 Bhavsar SK, Bobbala D, Xuan NT, Foller M, Lang F: Stimulation of suicidal erythrocyte death by alpha-lipoic acid. Cell Physiol Biochem 2010;26:859-868.

-19 Bhavsar SK, Eberhard M, Bobbala D, Lang F: Monensin induced suicidal erythrocyte death. Cell Physiol Biochem 2010;25:745-752.

20 Braun M, Foller M, Gulbins E, Lang F: Eryptosis triggered by bismuth. Biometals 2009;22:453-460.

-21 Eberhard M, Ferlinz K, Alizzi K, Cacciato PM, Faggio C, Foller M, Lang F: FTY720-induced suicidal erythrocyte death. Cell Physiol Biochem 2010;26:761-766.

22 Foller M, Kasinathan RS, Koka S, Lang C, Shumilina E, Birnbaumer L, Lang F, Huber SM: TRPC6 contributes to the $\mathrm{Ca}^{2+}$ leak of human erythrocytes. Cell Physiol Biochem 2008;21:183-192.

-23 Foller M, Sopjani M, Koka S, Gu S, Mahmud H, Wang K, Floride E, Schleicher E, Schulz E, Munzel T, Lang F: Regulation of erythrocyte survival by AMP-activated protein kinase. FASEB J 2009;23:1072-1080.

24 Brugnara C, de Franceschi L, Alper SL: Inhibition of $\mathrm{Ca}^{2+}$-dependent $\mathrm{K}^{+}$transport and cell dehydration in sickle erythrocytes by clotrimazole and other imidazole derivatives. J Clin Invest 1993;92:520-526.

-25 Lang PA, Kaiser S, Myssina S, Wieder T, Lang F, Huber SM: Role of $\mathrm{Ca}^{2+}$-activated $\mathrm{K}^{+}$channels in human erythrocyte apoptosis. Am J Physiol Cell Physiol 2003;285:C1553-C1560.

26 Berg CP, Engels IH, Rothbart A, Lauber K, Renz A, Schlosser SF, Schulze-Osthoff K, Wesselborg S: Human mature red blood cells express caspase- 3 and caspase-8, but are devoid of mitochondrial regulators of apoptosis. Cell Death Differ 2001;8:1197-1206.

27 Lang F, Gulbins E, Lang PA, Zappulla D, Foller M: Ceramide in suicidal death of erythrocytes. Cell Physiol Biochem 2010;26:21-28.

28 Klarl BA, Lang PA, Kempe DS, Niemoeller OM, Akel A, Sobiesiak M, Eisele K, Podolski M, Huber SM, Wieder T, Lang F: Protein kinase C mediates erythrocyte "programmed cell death" following glucose depletion. Am J Physiol Cell Physiol 2006;290:C244-C253.

29 Foller M, Huber SM, Lang F: Erythrocyte programmed cell death. IUBMB Life 2008;60:661-668.

30 Foller M, Mahmud H, Gu S, Wang K, Floride E, Kucherenko Y, Luik S, Laufer S, Lang F: Participation of leukotriene C(4) in the regulation of suicidal erythrocyte death. J Physiol Pharmacol 2009;60:135-143.

-31 Lau IP, Chen H, Wang J, Ong HC, Leung KC, Ho HP, Kong SK: In vitro effect of CTAB- and PEG-coated gold nanorods on the induction of eryptosis/erythroptosis in human erythrocytes. Nanotoxicology 2011; 6:84756.

32 Maellaro E, Leoncini S, Moretti D, Del Bello B, Tanganelli I, De Felice C, Ciccoli L: Erythrocyte caspase-3 activation and oxidative imbalance in erythrocytes and in plasma of type 2 diabetic patients. Acta Diabetol 2011; in press.

-33 Foller M, Feil S, Ghoreschi K, Koka S, Gerling A, Thunemann M, Hofmann F, Schuler B, Vogel J, Pichler B, Kasinathan RS, Nicolay JP, Huber SM, Lang F, Feil R: Anemia and splenomegaly in cGKI-deficient mice. Proc Natl Acad Sci U S A 2008;105:6771-6776.

-34 Brand VB, Sandu CD, Duranton C, Tanneur V, Lang KS, Huber SM, Lang F: Dependence of Plasmodium falciparum in vitro growth on the cation permeability of the human host erythrocyte. Cell Physiol Biochem 2003;13:347-356.

-35 Bookchin RM, Ortiz OE, Lew VL: Activation of calcium-dependent potassium channels in deoxygenated sickled red cells. Prog Clin Biol Res 1987;240:193-200.

-36 Bratosin D, Estaquier J, Petit F, Arnoult D, Quatannens B, Tissier JP, Slomianny C, Sartiaux C, Alonso C, Huart JJ, Montreuil J, Ameisen JC: Programmed cell death in mature erythrocytes: a model for investigating death effector pathways operating in the absence of mitochondria. Cell Death Differ 2001;8:1143-1156.

37 Lang KS, Duranton C, Poehlmann H, Myssina S, Bauer C, Lang F, Wieder T, Huber SM: Cation channels trigger apoptotic death of erythrocytes. Cell Death Differ 2003;10:249-256.

-38 Ghashghaeinia M, Cluitmans JC, Akel A, Dreischer P, Toulany M, Koberle M, Skabytska Y, Saki M, Biedermann T, Duszenko M, Lang F, Wieder T, Bosman GJ: The impact of erythrocyte age on eryptosis. Br J Haematol 2012;157:606-614.

39 Ensinger HA, Wahl D, Brantl V: Radioreceptor assay for determination of the antimuscarinic drug ipratropium bromide in man. Eur J Clin Pharmacol 1987;33:459-462. 
-40 Calderon-Salinas JV, Munoz-Reyes EG, Guerrero-Romero JF, Rodriguez-Moran M, Bracho-Riquelme RL, Carrera-Gracia MA, Quintanar-Escorza MA: Eryptosis and oxidative damage in type 2 diabetic mellitus patients with chronic kidney disease. Mol Cell Biochem 2011; 357(1-2):171-9.

41 Nicolay JP, Schneider J, Niemoeller OM, Artunc F, Portero-Otin M, Haik G Jr, Thornalley PJ, Schleicher E, Wieder T, Lang F: Stimulation of suicidal erythrocyte death by methylglyoxal. Cell Physiol Biochem 2006;18:223-232.

42 Myssina S, Huber SM, Birka C, Lang PA, Lang KS, Friedrich B, Risler T, Wieder T, Lang F: Inhibition of erythrocyte cation channels by erythropoietin. J Am Soc Nephrol 2003;14:2750-2757.

43 Lang PA, Beringer O, Nicolay JP, Amon O, Kempe DS, Hermle T, Attanasio P, Akel A, Schafer R, Friedrich B, Risler T, Baur M, Olbricht CJ, Zimmerhackl LB, Zipfel PF, Wieder T, Lang F: Suicidal death of erythrocytes in recurrent hemolytic uremic syndrome. J Mol Med 2006;84:378-388.

44 Kempe DS, Akel A, Lang PA, Hermle T, Biswas R, Muresanu J, Friedrich B, Dreischer P, Wolz C, Schumacher U, Peschel A, Gotz F, Doring G, Wieder T, Gulbins E, Lang F: Suicidal erythrocyte death in sepsis. J Mol Med 2007;85:273-281.

45 Lang PA, Kasinathan RS, Brand VB, Duranton C, Lang C, Koka S, Shumilina E, Kempe DS, Tanneur V, Akel A, Lang KS, Foller M, Kun JF, Kremsner PG, Wesselborg S, Laufer S, Clemen CS, Herr C, Noegel AA, Wieder T, Gulbins E, Lang F, Huber SM: Accelerated clearance of Plasmodium-infected erythrocytes in sickle cell trait and annexin-A7 deficiency. Cell Physiol Biochem 2009;24:415-428.

46 Siraskar B, Ballal A, Bobbala D, Foller M, Lang F: Effect of amphotericin B on parasitemia and survival of plasmodium berghei-infected mice. Cell Physiol Biochem 2010;26:347-354.

47 Bobbala D, Alesutan I, Foller M, Huber SM, Lang F: Effect of anandamide in Plasmodium Berghei-infected mice. Cell Physiol Biochem 2010;26:355-362.

48 Foller M, Bobbala D, Koka S, Huber SM, Gulbins E, Lang F: Suicide for survival--death of infected erythrocytes as a host mechanism to survive malaria. Cell Physiol Biochem 2009;24:133-140.

- 49 Koka S, Bobbala D, Lang C, Boini KM, Huber SM, Lang F: Influence of paclitaxel on parasitemia and survival of Plasmodium berghei infected mice. Cell Physiol Biochem 2009;23:191-198.

50 Lang PA, Schenck M, Nicolay JP, Becker JU, Kempe DS, Lupescu A, Koka S, Eisele K, Klarl BA, Rubben H, Schmid KW, Mann K, Hildenbrand S, Hefter H, Huber SM, Wieder T, Erhardt A, Haussinger D, Gulbins E, Lang F: Liver cell death and anemia in Wilson disease involve acid sphingomyelinase and ceramide. Nat Med 2007;13:164-170.

51 Kempe DS, Lang PA, Duranton C, Akel A, Lang KS, Huber SM, Wieder T, Lang F: Enhanced programmed cell death of iron-deficient erythrocytes. FASEB J 2006;20:368-370.

52 Birka C, Lang PA, Kempe DS, Hoefling L, Tanneur V, Duranton C, Nammi S, Henke G, Myssina S, Krikov M, Huber SM, Wieder T, Lang F: Enhanced susceptibility to erythrocyte "apoptosis" following phosphate depletion. Pflugers Arch 2004;448:471-477.

53 Zappulla D: Environmental stress, erythrocyte dysfunctions, inflammation, and the metabolic syndrome: adaptations to CO2 increases? J Cardiometab Syndr 2008;3:30-34.

54 Borst O, Abed M, Alesutan I, Towhid ST, Qadri SM, Foller M, Gawaz M, Lang F: Dynamic adhesion of eryptotic erythrocytes to endothelial cells via CXCL16/SR-PSOX. Am J Physiol Cell Physiol 2011;302:C644651.

55 Andrews DA, Low PS: Role of red blood cells in thrombosis. Curr Opin Hematol 1999;6:76-82.

-56 Closse C, Dachary-Prigent J, Boisseau MR: Phosphatidylserine-related adhesion of human erythrocytes to vascular endothelium. Br J Haematol 1999;107:300-302.

57 Gallagher PG, Chang SH, Rettig MP, Neely JE, Hillery CA, Smith BD, Low PS: Altered erythrocyte endothelial adherence and membrane phospholipid asymmetry in hereditary hydrocytosis. Blood 2003;101:46254627.

58 Pandolfi A, Di Pietro N, Sirolli V, Giardinelli A, Di Silvestre S, Amoroso L, Di Tomo P, Capani F, Consoli A, Bonomini M: Mechanisms of uremic erythrocyte-induced adhesion of human monocytes to cultured endothelial cells. J Cell Physiol 2007;213:699-709.

-59 Wood BL, Gibson DF, Tait JF: Increased erythrocyte phosphatidylserine exposure in sickle cell disease: flow-cytometric measurement and clinical associations. Blood 1996;88:1873-1880.

60 Chung SM, Bae ON, Lim KM, Noh JY, Lee MY, Jung YS, Chung JH: Lysophosphatidic acid induces thrombogenic activity through phosphatidylserine exposure and procoagulant microvesicle generation in human erythrocytes. Arterioscler Thromb Vasc Biol 2007;27:414-421.

61 Zwaal RF, Comfurius P, Bevers EM: Surface exposure of phosphatidylserine in pathological cells. Cell Mol Life Sci 2005;62:971-988. 